\title{
90th Birth Anniversary of Academician N.P. Laverov
}

DOI: $10.1134 / \mathrm{S} 107570152001002 \mathrm{X}$

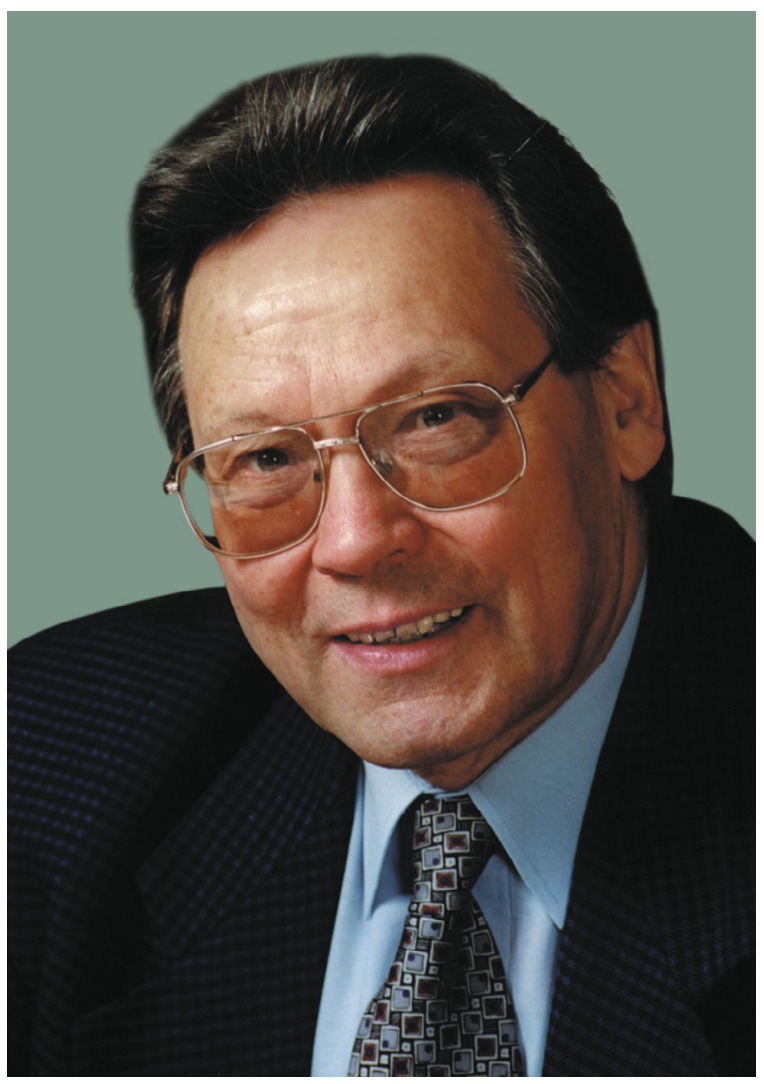

Dear colleagues, it is my great pleasure to present this special issue of Geology of Ore Deposits, dedicated to the memory of Academician Nikolai Pavlovich LAVEROV. On January 12, 2020, Nikolai Pavlovich would have been 90 years old. He was a student of the founder of our journal, Academician Anatoly Georgievich Betekhtin, and from 1988 through 2005, its editor-in-chief.

N.P. Laverov has been acknowledged as a leader among Soviet and Russian scientists in the field of geology and ore deposits. He pioneered studies of uranium mineralization related to intracontinental volcanism and discovered a new genetic type of uranium deposits. He developed the theory of evolution of uranium ore formation processes in Earth's history and revealed global patterns in the mineralization of various deposits. He made a vast contribution to develop- ing high-performance technologies for exploring uranium deposits using subsurface leaching methods. For many years, this provided our country with raw materials and made it a world leader in the nuclear industry. Laverov founded the scientific direction of radioecology, the scientific bases of environmental protection from radioactive contamination.

This special issue has collected papers of Laverov's students and colleagues that develop his ideas and concepts of the geology and origin of uranium deposits and historical metallogeny. The article by V.N. Golubev et al. is devoted to the geochronology of Kazakhstan's uranium deposits. Laverov always gave primary importance to dating ore deposits, rightfully noting that knowledge of the age of ore processes is crucial both for creating a theory of ore formation and predicting deposits. B.T. Kochkin's article is a review of modern concepts on the origin of exogenic infiltration uranium deposits and their relationship to ascending subsurface water. It should be recalled that Laverov particpated in creating a technology for mining such deposits using subsurface leaching. The article by A.A. Pek et al. considers a uranium deposit model related to the Streltsovka caldera. It proposes a heat and mass transfer model that hypothesizes the uranium sources in this system. Laverov one of the first to develop concepts on hydrothermal fluid filtration along fault zones. The article by A.V. Tkachev et al. develops Laverov's ideas on historical metallogeny; Laverov's friend, Academician D.V. Rundkvist, participated in its writing. The article by O.V. Andreeva et al. characterizes the metallogeny of Transbaikalia and demostrates its relationship to Mesozoic felsic magmatism. It also develops Laverov's concepts on uranium deposit metallogeny.

The editorial board thanks the scientists invited to participate in this special issue, a tribute of deep respect and warm memory to a wonderful person and distinguished geologist. N.P. Laverov was a stark person that drew people with his intelligence, integrity, optimism, and willingness to listen. Nikolai Pavlovich Laverov will remain in our memory as a person who devoted his life in service to his country.

Editor-in-Chief Nikolay Bortnikov 